University of Nebraska - Lincoln

DigitalCommons@University of Nebraska - Lincoln

Architecture Program: Faculty Scholarly and

Creative Activity

Architecture Program

$9-2010$

\title{
Using Popular Film in the Architectural History Classroom
}

\author{
Rumiko Handa \\ University of Nebraska-Lincoln, rhanda1@unl.edu
}

Follow this and additional works at: https://digitalcommons.unl.edu/arch_facultyschol

Part of the Architecture Commons

Handa, Rumiko, "Using Popular Film in the Architectural History Classroom" (2010). Architecture Program: Faculty Scholarly and Creative Activity. 13.

https://digitalcommons.unl.edu/arch_facultyschol/13

This Article is brought to you for free and open access by the Architecture Program at DigitalCommons@University of Nebraska - Lincoln. It has been accepted for inclusion in Architecture Program: Faculty Scholarly and Creative Activity by an authorized administrator of DigitalCommons@University of Nebraska - Lincoln. 


\section{Using Popular Film in the Architectural History Classroom}

RUMIKO HANDA

University of Nebraska-Lincoln
$\mathrm{I}$ n 1945 Béla Balázs, the Hungarian author, film director, and critic, observed that motion pictures had revived the language of the human body and facial expressions, which had been subdued by print culture: "The first new world discovered by the film camera in the days of the silent film was the world of very small things visible only from very short distances, the hidden life of little things. ... By means of the close-up the camera in the days of the silent film revealed also the hidden mainsprings of a life which we had thought we already knew so well. In the days of the silent film [the close-up] not only revealed new things, but showed us the meaning of the old." More than half a century later, and more than a century and a half after Victor Hugo's statement that the printed book had surpassed architecture in communicative efficacy ("This will kill that"), Balázs's observation of the revelatory character of film cannot be taken lightly by those who teach architecture and architectural history. ${ }^{2}$ While film uses mechanisms that are unfamiliar and even counterintuitive to us, it can present the dramatic power of architecture. Used carefully, popular films can enliven architectural history classes. ${ }^{3}$

Journal of the Society of Architectural Historians 69, no. 3 (September 2010), 311-19. ISSN 0037-9808, electronic ISSN 2150-5926. ( 2010 by the Society of Architectural Historians. All rights reserved. Please direct all requests for permission to photocopy or reproduce article content through the University of California Press's Rights and Permissions website, http://www.ucpressjournals.com/reprintlnfo.asp. DOI: 10.1525/jsah.2010.69.3.311.

\section{Buildings in Popular Films}

To place actors in an actual building instead of on a set is a comparatively new trend in filmmaking, and in the beginning it was a debatable proposition. ${ }^{4}$ The director Marcel L'Herbier (Veille d'Armes, 1935) reacted against the incorporation of the real into filmic fiction. However, Virgilio Marchi, the art director of Italian Neorealist films (Umberto D., 1952; Stazione Termini, 1951) argued for the realistic representation of daily life, to be attained by location shoots, and questioned the use of spectacular studio sets. The production designer Jean André (La Vérité, 1960) similarly condemned the construction of "excellent" studio sets for diverting resources and attention away from scripts and actors.

In recent years, directors increasingly have shot important popular films in real buildings, and in this they have been aided by the caretakers of many sites, who are eager to offer filming locations. For instance, for The Da Vinci Code (2006, based on Dan Brown's 2003 bestseller), the Louvre agreed to accommodate the film crew, and museum director Henri Loyrette said, "There is really a very strong desire to see the film adaptation of this book ... shot at the Louvre." ${ }^{5}$

Such moviemaking has led to an increase in film tourism, which began to surge in the mid-1990s. ${ }^{6}$ The Da Vinci Code attracted people to a number of sites, from the already popular Louvre and Westminster Abbey to the lessfrequented St. Sulpice in Paris, and even less-known Rosslyn 
Chapel near Edinburgh. ${ }^{7}$ Each location experienced a significant increase in visitors, many of whom came expecting to examine in the building the themes relating to the novel, such as the Holy Grail legend or Mary Magdalene's role in the history of Christianity.

In the year following the release of the film Little Women (1994) there was a 65 percent increase in visitors to Orchard House in Concord, Massachusetts. After Hugh Grant and Andie MacDowell's first night in Four Weddings and a Funeral (1994), the Crown Hotel, a quaint Elizabethan coaching inn about 30 miles northwest of London, was booked full for at least three years. In 1996 the Wallace Monument outside Stirling, Scotland, saw its visitation quadruple in the wake of Braveheart (1995), while Lyme Park in Cheshire, England, saw a 150 percent increase after standing in for Pemberley in the BBC/A\&E production of Pride and Prejudice (1995). The Harry Potter series (2001, 2002, 2004, 2005, 2007, and 2009) caused an increase in visitors of at least 50 percent at many locations, including Oxford University's Christ Church College, the Bodleian Library, and Gloucester cathedral, while Troy's tourism shot up 73 percent after the 2004 release of the film with the same title. Guided tours may be offered based on particular films, from the Harry Potter tours in Oxford and Gloucester to the "official" Angels and Demons tour of Rome, and guidebooks are published for those interested, such as The Making of Pride and Prejudice, based on the BBC series. ${ }^{8}$

Popular film's unprecedented success in attracting large audiences to historical sites translates into increased and focused student interest in buildings that are physically and culturally distant and that otherwise would seem to have little relevance to their studies. This is a powerful tool for teachers, but its effects will be superficial unless students are led to understand the film techniques that imitate architectural reality.

\section{Scale and Three-Dimensionality}

Some of the alluring power of popular films rests on the sense of being there. The mechanisms of film instill in the audience a sense of affinity for the building through the virtual experience of inhabiting filmic space. Film may thus complement other means of representation traditionally used in architectural history classes.

In demonstrating a building's scale, film not only contrasts it with human figures or other objects to which the audience easily can relate, but also allows the building to overflow the screen, which is already larger than the audience's field of vision. These mechanisms differ from our own habits in taking architectural photographs. Anticipating classroom use, we equip ourselves with wide-angle

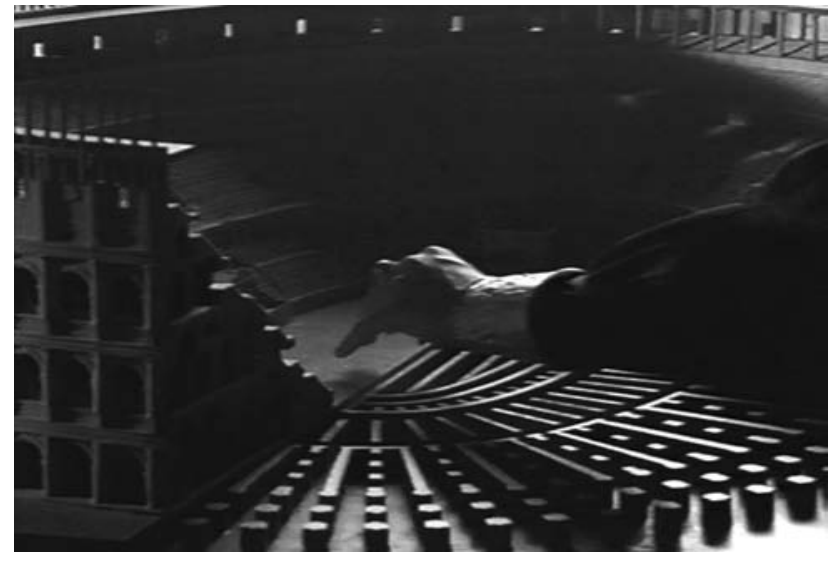

Figure 1 Gladiator, Ridley Scott, 2000, Commodus at play with Coliseum model (see JSAH online for film clip)

and telephoto lenses for the purpose of fitting our subject precisely within the field of vision, and we intuitively avoid people or cars, which not only obstruct the view of the building but also distract the viewer by inviting speculation about when the photograph was taken. Film does the opposite, spilling over the edges of the projection surface and filling space with human action.

The film Gladiator (2000) uses both these mechanisms to maximum effect in portraying the Roman Coliseum (Figure 1). The sequence begins with black-and-white footage in which Emperor Marcus Aurelius's son Commodus plays with toy figures on a model of the amphitheater, enjoying his recently acquired power as the emperor. When the camera moves up and above the outer wall, Commodus is no longer in the picture, and the model is replaced by a fullscale depiction of chariots, horses, and gladiators. A computer-generated Coliseum then takes over, by now in full color, and its enormity is stressed first by our realization that even the large screen cannot capture the building entirely, as the camera's angle moves slowly upward in search of the top of the building, and second in comparison to Russell Crowe and his colleague gladiators who are marshaled on the ground outside.

Architects, of course, long have had ways of depicting three-dimensionality on two-dimensional surfaces, with perspective and other graphic constructions. In still photography the perception of depth also was made possible, through the use of stereography. Invented by Sir Charles Wheatstone in 1838 , the stereograph uses two stationary photographs with binocular discrepancy. The viewer, with the help of equipment, sees one image with the right eye and the other with the left, and the brain combines the two images to create a three-dimensional perception. Stereography was a popular entertainment for Victorians, who enjoyed 
three-dimensional visions of exotic places and unfamiliar objects that were available at London's shops and expositions. The principles of stereoscopy still are used for 3-D films, which consist of two overlapping images that are viewed by an audience wearing polarized eyeglasses.

Film, not unlike perspectives or photographs, is an image projected on a flat screen. But unlike the architect's drawings or even stereography, film uses time to depict an object's three-dimensionality. The motion-picture camera may move through space or turn while taking a picture. When the camera's position and angle both are fixed, it still may change the view by zooming in or out, or, when everything about the camera is still, human figures may move through space. The advantage of relying on time to convey three-dimensionality is that unlike stereography, film requires no intermediary device or forced point of view. The viewing of film is as natural as watching things go by at a sidewalk café, making the sense of inhabiting the space more real than any other means of representation.

Belgian director Gérard Corbiau's Le Roi Danse (2000) is a film about Louis XIV of France, who used the performing arts-dance, music, and theater-to demonstrate his power and glory as the Sun King. ${ }^{9}$ Throughout the film, the evolving state of the kingship is captured in the relationship of the monarch to the architecture of Versailles, and in the closing scene the aging king mourns the death of his music director, Jean-Baptiste de Lully (and his own declining power) in the Hall of Mirrors as he looks at the setting sun with the Grand Canal disappearing toward the horizon in glowing orange. As the king walks away, the stationary camera looks longitudinally down the hall. The camera moves sideways slightly to change the perspective until the central row of chandeliers lines up in the final image (Figure 2). As the king disappears from view, we are left with the space filled with the sun's rays reflected in the mirrors, floor, and chandeliers. The scene demonstrates, much more effectively than any still images, the location and orientation of the hall and the organization of the canals, which were constructed by Louis XIV with designs provided by Jules Hardouin Mansart and André Le Nôtre.

Bernardo Bertolcci's The Last Emperor (1987) portrays the life of Puyi, the last emperor of the Qing dynasty, which ended the long chain of Chinese dynasties. ${ }^{10}$ The Forbidden City changes its appearance as Puyi's political status evolves: colorful and decorated at the time of coronation (1908), vast but empty at the time of his abdication (1912), and a lifeless cultural artifact of the Republic of China. The authoritarian effect of the site's arrangement along the central axis is clear in the scene of coronation, in which the infant emperor runs out of the Hall of Supreme Harmony under the hanging cloths to discover row after row of kowtowing people. The prodigious size of the palace complex is apparent when the camera follows the toddler emperor down the steps and slowly turns to reveal another vast crowd in the lower courtyard (Figure 3).

Together with conveying scale and three-dimensionality, the large and wide projection screen creates the sense of inhabiting filmic space by allowing the image to fill and then apparently overflow the field of vision.

Take, for example, the film Elizabeth (1998), directed by Shekhar Kapur with Cate Blanchett as Elizabeth I, and the coronation ceremony in particular (Figure 4). In that scene, Elizabeth progresses through the nave, led by William Cecil and watched by the audience that fills the cathedral. The procession slowly advances on a red carpet woven with the Tudor rose pattern until it reaches the throne, which is

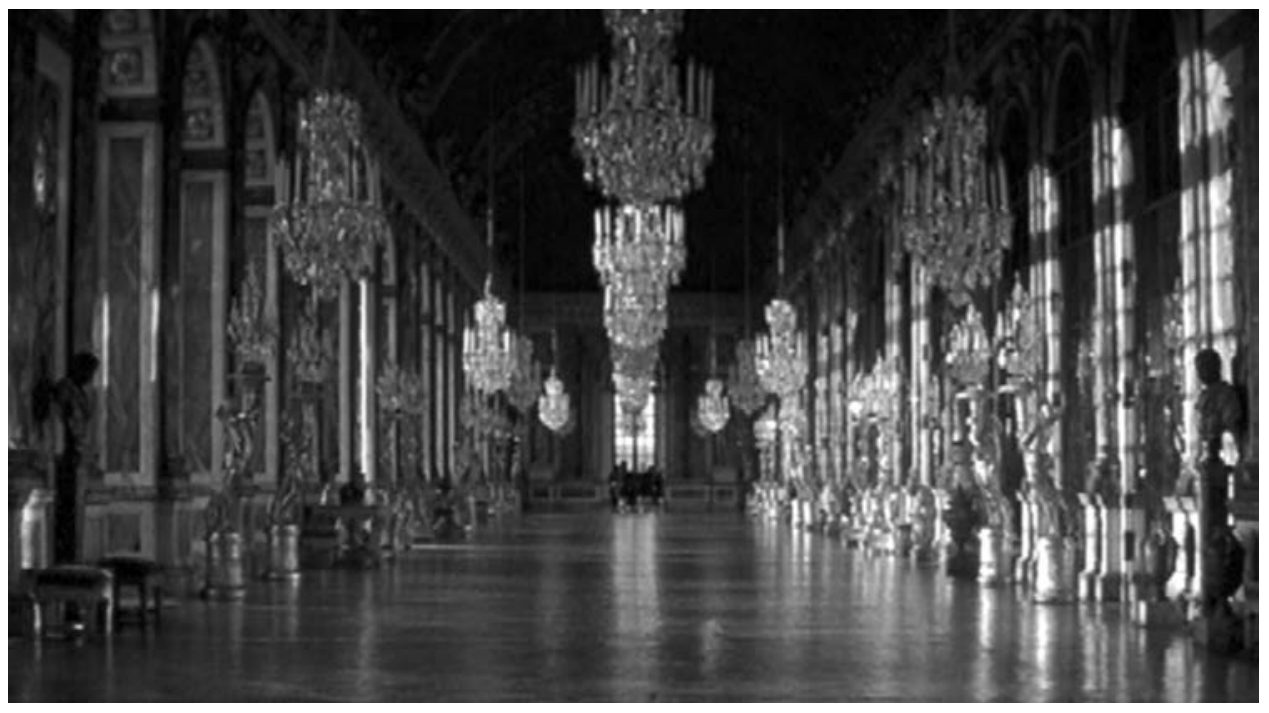

Figure 2 Le Roi Danse, Gérard Corbiau, 2000, final scene in the Hall of Mirrors (see JSAH online for film clip) 


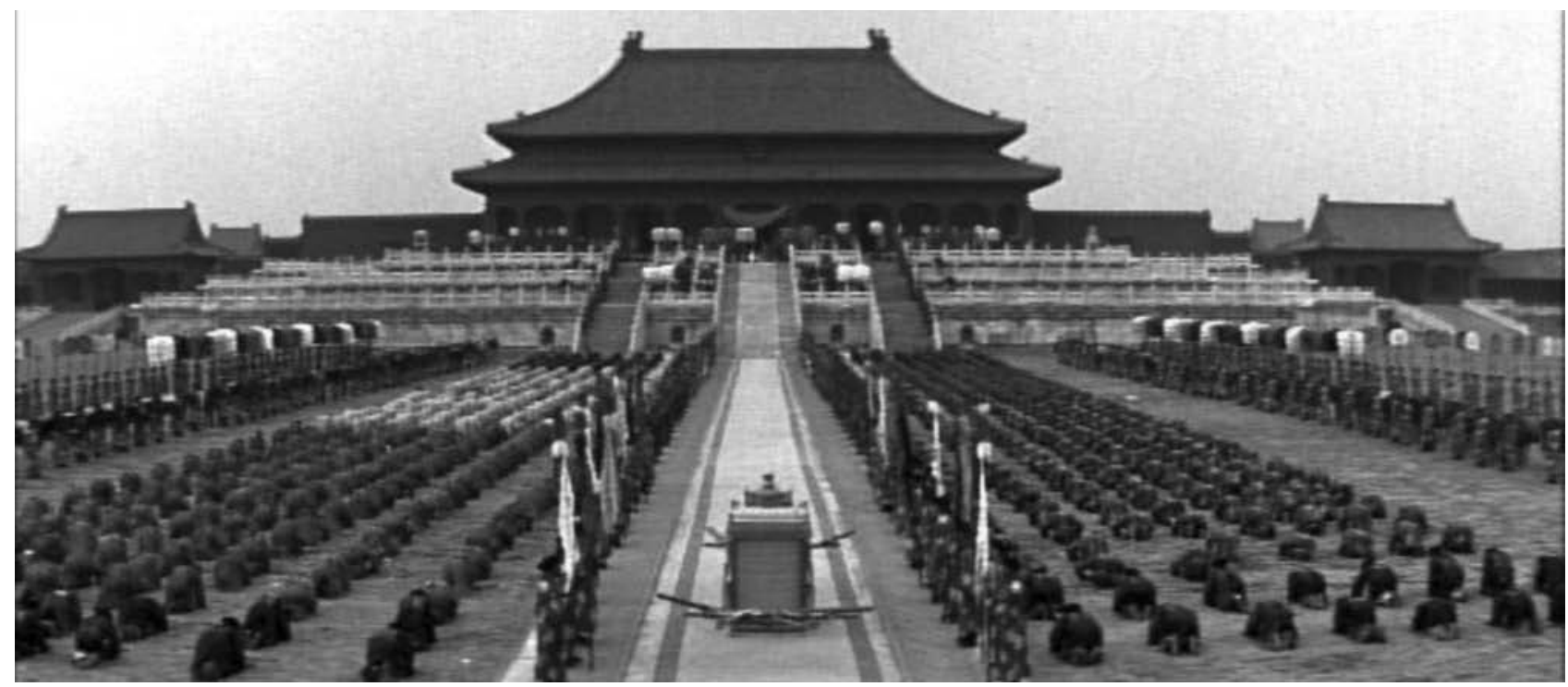

Figure 3 The Last Emperor, Bernardo Bertolucci, 1987. Puyi is received by his subjects outside the Hall of Supreme Harmony (see JSAH online for film clip)

placed on a raised stage under the church's crossing. The film places the viewer among the audience by setting the camera at their eye level. At first the stationary camera "stands" among the audience on the temporary balcony built over the south aisle. In order to fill the wide screen without peripheral distortion, the scene employs the technique that Raphael used in his famous interior sketch of the Pantheon (Uffizi 164 A.r.), inconspicuously splicing two images together: the right half is taken from an angle almost parallel to the church's axis, and the left half is taken from slightly higher than eye level and from a diagonal angle looking toward the north transept. Once the viewer has grasped the overall scale of the space from above and afar, the viewpoint shifts to the ground floor. Here the viewer once again stands among the ceremonial audience, observing Elizabeth's procession from a close proximity.

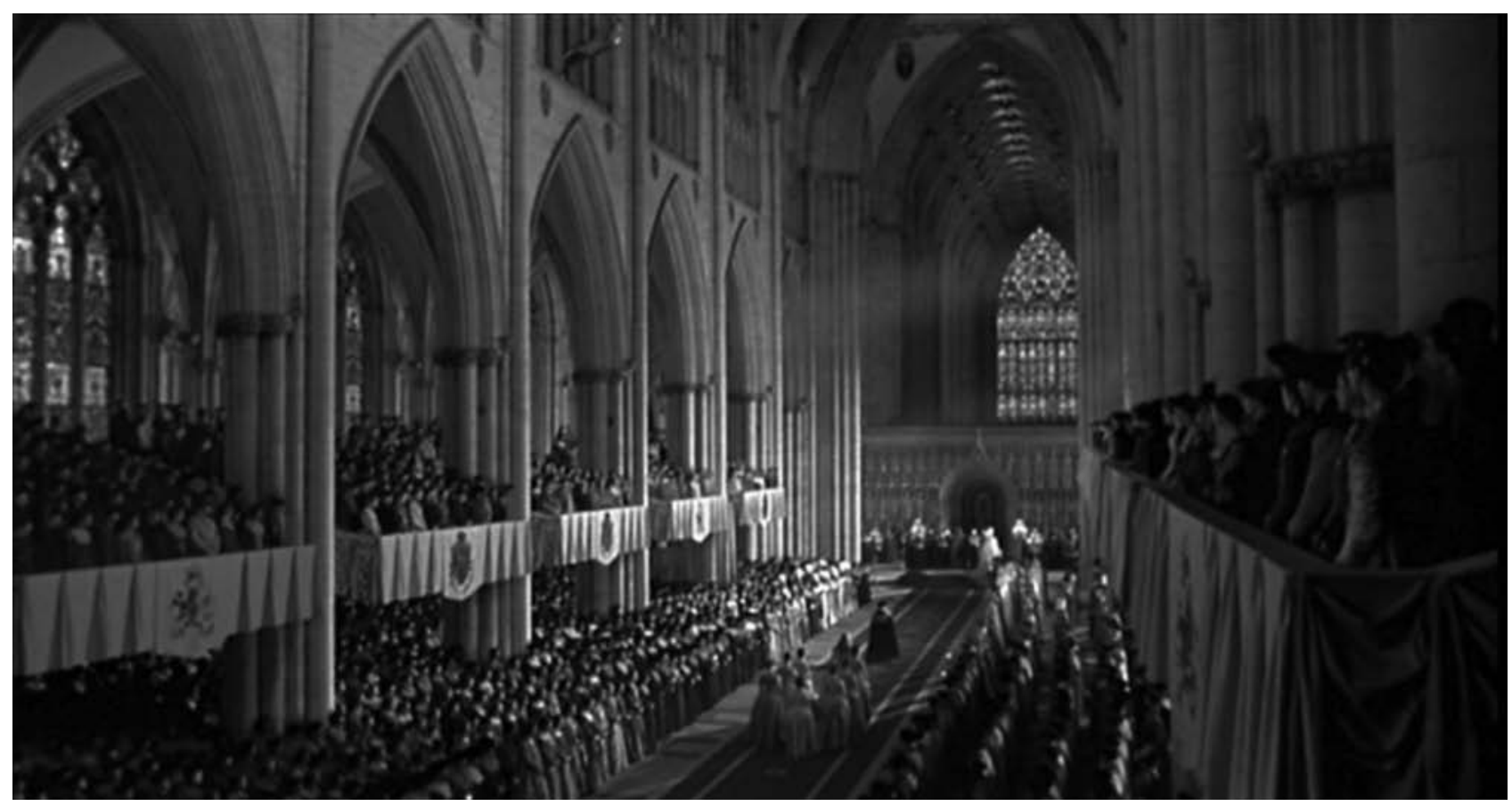

Figure 4 Elizabeth, directed by Shekhar Kapur, 1998, coronation procession (see JSAH online for film clip) 


\section{The Problem of Accuracy}

While scale, three-dimensionality, and the semblance of inhabiting the space are advantages that film brings to architectural representation, if these were its sole capacities it would be only a surrogate for the actual building. A film, however, creates its own actualities and, as Barry Bergdoll has pointed out, film's horizontal frame restructures our appreciation of vertical spaces and forms, and a film imposes a structured sequence of viewing positions that may not coincide with the historian's argument. ${ }^{11}$

Of more serious concern is the lack of historical accuracy in many popular films. This affects everything about them, not just their depictions of architecture. For example, the historical Emperor Marcus Aurelius died of chicken pox, not at the hand of Commodus as shown in Gladiator, and Russell Crowe's Maximus is a fictional figure. With the actual Coliseum in ruins, the filmic version was produced by computer graphics in defiance of today's reality. The Last Emperor has been criticized for ignoring important issues of modern Chinese history, including the Japanese occupation of Manchuria and the relationship between Puyi and the Japanese forces. Both the amphitheater and hall scenes of $L e$ Roi Danse were shot at Versailles, and the final sequence in the Hall of Mirrors is accurate historically insofar as that room was completed in 1684, three years before Lully's death. However, the scene was filmed before the most recent renovation of 2004-7, and so the Hall of Mirrors appears darker than it would have in the seventeenth century-with fogged mirrors, paintings obscured by varnish, and discolored parquet floors. And the chandeliers would need to be lit with candles to give an accurate impression of the setting. ${ }^{12}$

In Elizabeth, the coronation scene was filmed at York Minster instead of Westminster Abbey, and the notable differences between those buildings require examination. While their overall sizes and proportions are dissimilar, it is the difference in their interior elevations that is most striking. ${ }^{13}$ Westminster Abbey has a strongly expressed threestory elevation, whose middle or triforium level is lit by exterior openings (Figure 5). This feature invited Sir George Gilbert Scott to suggest that the triforium at Westminster had been intended to accommodate sightseers on grand occasions. ${ }^{14} \mathrm{~A}$ woodcut depicting the coronation of George IV in 1821 shows the audience occupying the triforium as well as steps and balconies built within the arcade level, very likely the same arrangement that was made for Elizabeth in 1559. ${ }^{15}$ At York, however, the triforium is tucked under the roof and unlit, and in the film the triforium at York is empty (Figure 6).

And whereas at Westminster the divisions between arcade, triforium, and clerestory are made clear by the horizontal moldings that run across the bays and by the difference in the pattern of openings on each level (two openings in the clerestory, four in the triforium, and one in the ground

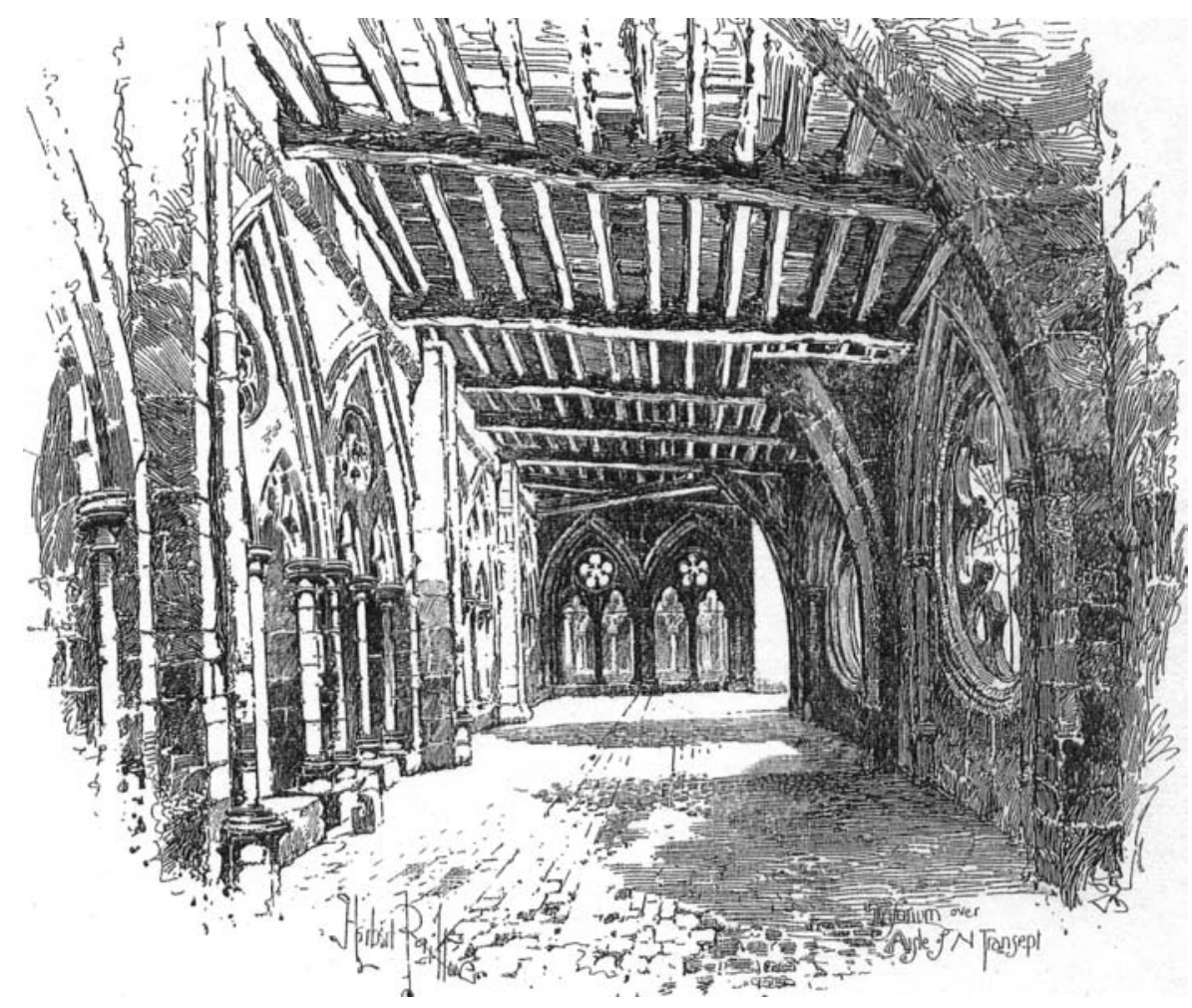

Figure 5 Westminster Abbey, inside the triforium (from The Portfolio: An Artistic Periodical 20 [1889], 123) 


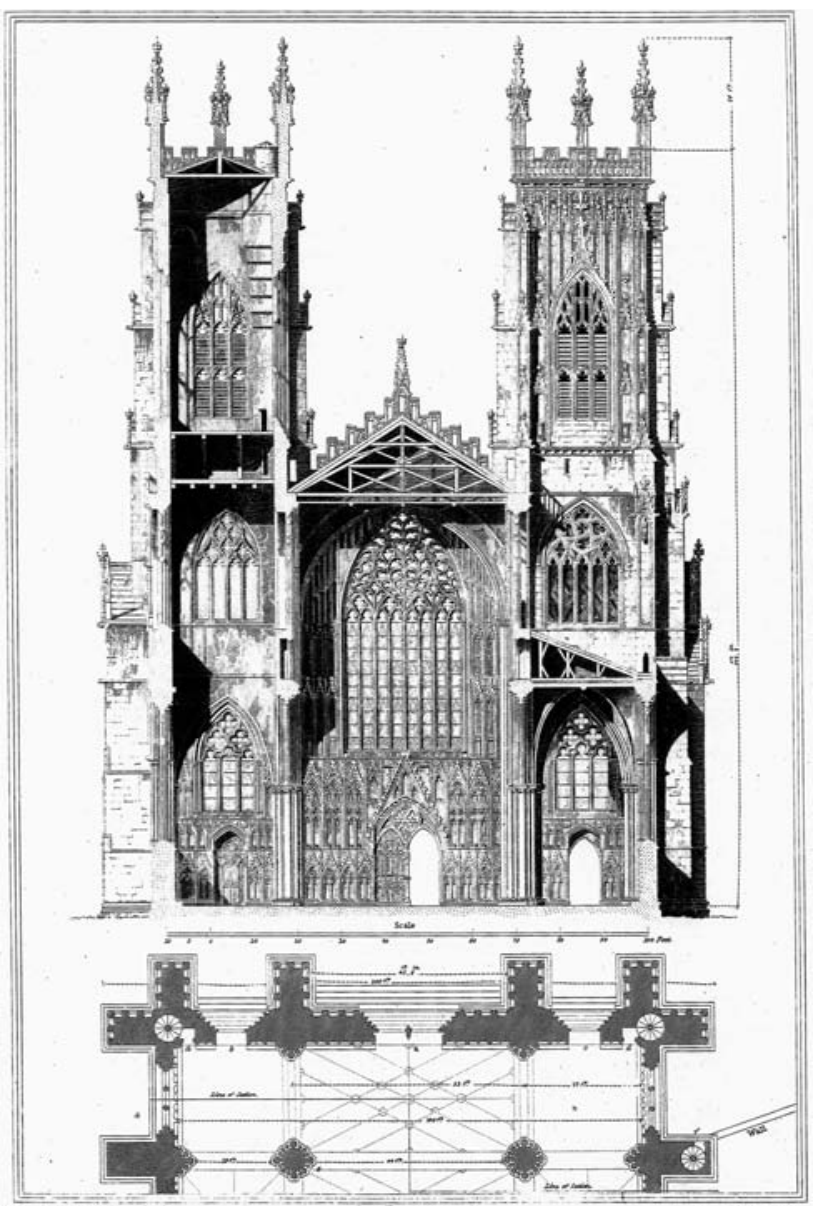

Figure 6 York Minster, cross section and partial plan (from John Britton, Cathedral Antiquities, vol. 1 [London: M. A. Nattali, 1836])

arcade), York at first appears to be a two-story building (Figure 7). ${ }^{16}$ While the division between the arcade and the triforium at York is made clear with horizontal lines and the discontinuity of vertical lines, the break between the clerestory and triforium is almost undetectable, because the horizontal moldings are suppressed and the shafting and the vertical mullions continue through. Both clerestory and triforium have five openings as well.

Another important difference between Westminster Abbey and York Minster is the location of the choir, which bears great significance in the coronation ceremony. At Westminster, the choir is west of the crossing, while at York, it is accommodated in the long eastern transept. ${ }^{17}$ At the coronation of Elizabeth I as well as that of Elizabeth II, the coronation theater was placed in front of the high altar and the monarch proceeded through the choir to be crowned. The ceremony took place directly below the crossing, with the greatness of the tower giving an appropriate spatial effect. One of the less welcome consequences of this spatial arrangement, however, is that the

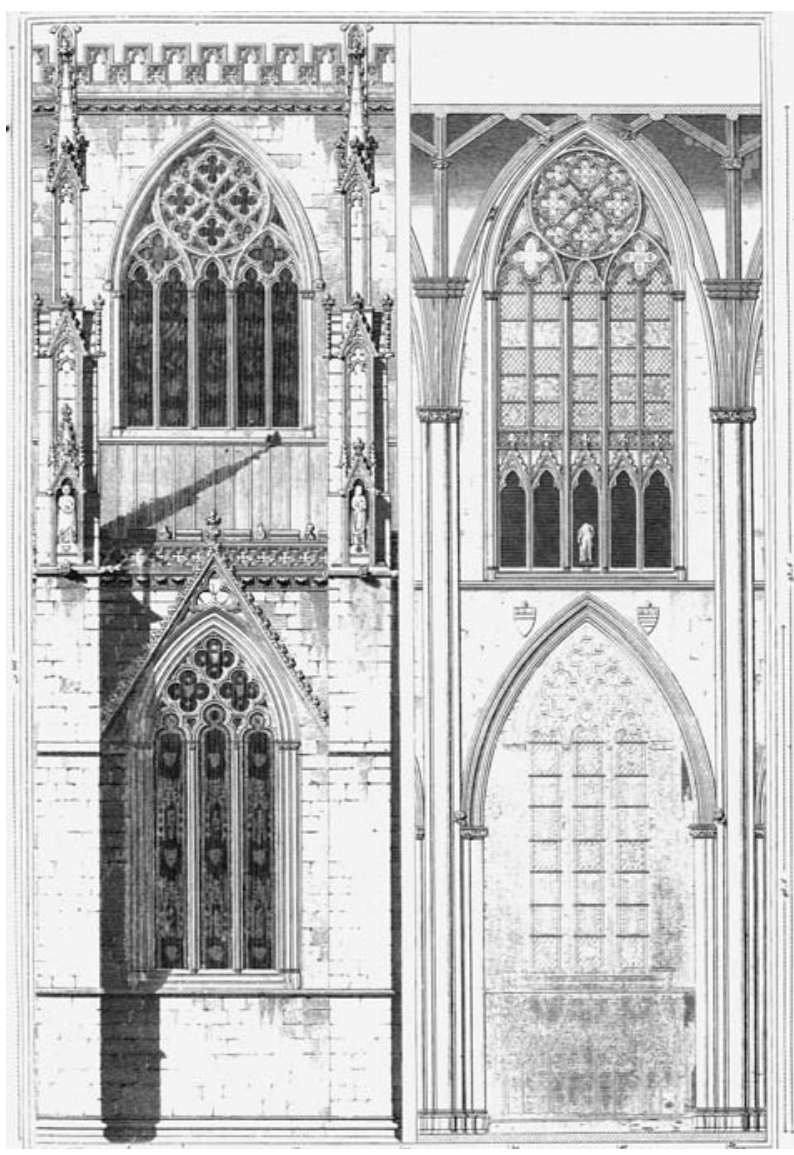

Figure 7 York Minster, interior and exterior nave elevations (from Britton, Cathedral Antiquities, vol. 1)

choir obscures the ceremony from the audience located further west in the nave. To film the coronation under the crossing at York, with the soaring tower above the ceremony, the theater had to be placed in front of the choir screen and not in front of the high altar.

If understood by the teacher, the stratagem by which York was able to stand in for Westminster in Elizabeth can be the basis for a fruitful discussion of Gothic interior elevations and floor plans.

\section{Human Aspects of Architecture}

Although a popular film may not depict a building accurately in all respects, it can convey very effectively the emotional, psychological, sociocultural, or political facets of human life in which architecture participates. This is difficult to communicate by other means.

In The Last Emperor, for example, the contrast between the toddler emperor and the Forbidden City transcends that of size to make a sociopolitical statement. The large capital 
complex, constructed in the early fifteenth century during the Ming dynasty, is a representation of things greater than physical size- the long span of dynastic rule (going back to 2000 BC), the twenty-four emperors of the Ming and Qing dynasties who reigned from the building, and the far-flung territories under their rule, which eventually included Manchuria to the north and Xinjiang and Tibet to the west. When the tiny toddler stands on the central axis that extends from the Hall to the courtyard and beyond, the architecture performs something like the human kowtowing that is taking place in the vast courtyard: continuing to practice a onceimportant ritual, which has become a formal exercise devoid of socio-political signification. The narrow alleys between high walls that connect numerous courtyards within the Inner Court are open only to the sky above, indicating the emperor's extreme detachment from everyday life.

Hiroshi Teshigahara's Rikyu (1989) is based on the Japanese novelist Yaeko Nogami's masterpiece Hideyoshi and Rikyu (1964), which depicts the conflict between the tea master Sen no Rikyu and shogun Toyotomi Hideyoshi. The film displays the contrast between Hideyoshi's opulent goldgilded tearoom and Rikyu's small tea hut made of unfinished timber and mud, an embodiment of wabi, the quality of an object that has lost something or deteriorated, and thus invites the viewer to imagine its perfect state. ${ }^{18}$ The differences in architecture are also those of the two individuals and their political and cultural positions. Hideyoshi, on the one hand, is a tyrannical ruler, having united all the warlords of Japan, but he grew up as a farmer's son in a region known for its vulgar dialect. On the other hand, Rikyu, born in the wealthy merchant city of Sakai, had already served as the celebrated tea master of shogun Oda Nobunaga, who preceded and ruled over Hideyoshi before being toppled in a coup d'état by another warlord.

The film depicts a legendary event involving these historical figures, which is set in a building that resembles Tai-an, a historical two-mat teahouse designed by Rikyu. Hideyoshi, having heard of the beauty of blooming morning glories in the garden of Rikyu's house, demands a visit. ${ }^{19} \mathrm{He}$ arrives early in the morning, but no flowers are to be seen. Puzzled, he enters the tearoom through its small, low doorway. As he looks up from his crawling position, he understands. Rikyu has arranged one flower for display, destroying the rest (Figure 8).

The actors' facial expressions make clear their feelings without words. Rikyu is disgusted and troubled by the shogun's garish taste and his desire to flaunt his power and wealth. Hideyoshi observes the cramped entrance that does not allow the samurai to carry his sword, the dainty white flower brought in from outside, the low ceiling that precludes

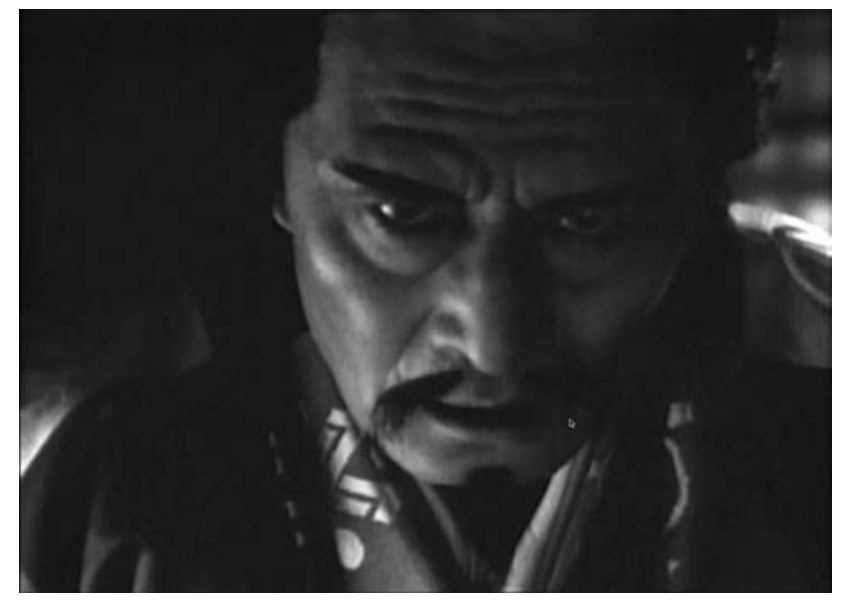

Figure 8 Rikyu, Hiroshi Teshigahara, 1989, Hideyoshi in Rikyu's tea room (see JSAH online for film clip)

any large display on the wall, and the lack of spatial hierarchy, which voids the power relationship between the tea server and guest. He cannot but concede the sophistication and superiority of his tea advisor and political confidant. Disturbingly, this leads to his demand for Rikyu's seppuku (ritual suicide by disembowelment).

In its power to display the human life of architecture, popular film surpasses videos produced for educational purposes and computer-generated three-dimensional models. ${ }^{20}$

\section{Film Montage}

Filmmakers have been interested in psychological dimensions since shortly after the invention of their medium. In the 1920s Expressionist films such as The Cabinet of Dr. Caligari (1920) experimented with physically distorted sets in order to show the psychological state of the protagonists. But filmmakers quickly realized that the same, or even stronger, effects could be achieved by the combination of different shots. ${ }^{21}$ Movement of the camera or subjects, change of focal length, and above all montage could demonstrate much in film, including the human aspects of architecture. $^{22}$

Montage can transform a physical event enacted in front of the camera into a psychological drama staged in front of the audience. As Hugo Münsterberg, a German-American psychologist, put it: "the events are seen in continuous movement; and yet the pictures break up the movement into a rapid succession of instantaneous impressions. We do not see the objective reality, but a product of our own mind which binds the pictures together ... the photoplay tells us the buman story by overcoming the forms of the outer world, namely, space, time, and causality, and by adjusting the events to the forms of the 
inner world, namely, attention, memory, imagination, and emotion. [emphasis in original]"23

The viewer participates in the filmic event as a member of the filmic audience (Elizabeth) or as the protagonist (The Last Emperor). The viewer sometimes is a privileged witness of private actions (Rikyu) or of facial features (Rikyu and Le Roi Danse). At other times the camera shows the impossible (a bird's-eye view) or invisible (a mental image). Above all, montage treats all points of view equally, as Hans Dieter Schaal observed: "It is as though the individual view had been duplicated, as though everyone's view was being shown simultaneously or in quick succession. The camera jumps and tracks from one point of view to the next, as if from one ego to another. The total number of views adds up to one image, to a sequence as in a Cubist picture. Time and space are democratized and shared evenly between everybody. Every sightline is equally valid." ${ }^{24}$ Montage engages the viewer in the emotional and psychological states of all the characters who give human drama to the physical environment that is depicted on the screen. It can introduce the audience in the architectural classroom to the audience of architecture.

Putting popular films to use in the classroom offers many opportunities, starting with the mass appeal that recent movies bring to the study of architecture. More significantly, film can help to teach how architectural scale and space affect the viewer. The historical inaccuracies of many movies can provide teachable moments for the discussion of significant architectural issues. And, surely most importantly, film can breathe human life into the spaces of architecture, allowing students to meet the audience of architecture-past, present, and future.

RUMIKO HANDA University of Nebraska-Lincoln

\section{Using Film in the Classroom}

This article provides only recommendations of film clips for classroom use and is not intended to offer legal advice about permissions to individuals or educational institutions concerning use of the clips.

\section{Notes}

1. Béla Balázs, Theory of Film: Character and Growth of a New Art (New York: Roy Publishers, 1953).

2. Victor Hugo, The Hunchback of Notre Dame, trans. Catherine Liu (New York: Modern Library, 2002). For the discussion of "This will kill that," see: Neil Levine, "The Book and the Building: Hugo's Theory of Architecture and Labrouste's Bibliothèque Ste-Geneviève," in The Beaux-Arts and Nineteenth-Century French Architecture, ed. Robin Middleton (Cambridge: MIT Press, 1982), 138-73; and Marin Bressani and Marc Grignon, "Henri Labrouste and the Lure of the Real: Romanticism, Rationalism and the Bibliothèque Sainte-Geneviève," in About Stephen Bann, ed. Deborah Cherry (Oxford: Blackwell, 2006), 140-79.

3. The use of film in representing and teaching architecture has been the subject of earlier scholarship. While Dietrich Neumann's important exhibition and the resultant book dealt with the capacity of film to realize the "boldest dreams (and worst nightmares)," the present study examines popular films that portray actual built architecture. Neumann, ed., Film Arcbitecture: Set Designs from Metropolis to Blade Runner (Munich and New York: Prestel, 1996). Barry Bergdoll has considered the use of film in architectural history teaching focusing on the "cinematic representation of reality." Bergdoll, "Altered States of Vision: Film, Video, and the Teaching of Architectural History," in Architecture on Screen: Films and Videos on Arcbitecture, Landscape Architecture, Historic Preservation, City and Regional Planning, ed. Nadine Covert (New York: G.K. Hall, 1993), xv-xx. In contrast, the present study suggests that film's most important classroom contributions are the emotional and psychological aspects of the architectural experience.

4. Charles Affron and Mirella Jona Affron, Sets in Motion: Art Direction and Film Narrative (New Brunswick, N.J.: Rutgers University Press, 1995), 24-26.

5. Carole Corm, compiled by Lawrence van Gelder, "Arts, Briefly; A New 'Da Vinci' for the Louvre," New York Times, 22 Jan. 2005, http://query. nytimes.com/gst/fullpage.html? res=990DE0DF1E38F931A15752C0A963 9C8B63 (accessed 27 May 2008).

6. Simon Hudson and J.R. Brent Ritchie, "Promoting Destinations via Film Tourism: An Empirical Identification of Supporting Marketing Initiatives," Fournal of Travel Research 44 (May 2006), 387-96. Other relevant articles include: Roger W. Riley and Carlton S. Van Doren, "Movies as Tourism Promotion: A 'Pull' Factor in a 'Push' Location," Tourism Management 13, no. 3 (1992), 267-74; Nichola Tooke and Michael Baker, "Seeing is Believing: The Effect of Film on Visitor Numbers to Screened Locations," Tourism Management 17, no. 2 (1996), 87-94; and Roger Riley, Dwayne Baker, and Carlton S. Van Doren, "Movie Induced Tourism," Annals of Tourism Research 25, no. 4 (1998), 919-35.

7. By 2006 the book had sold 60.5 million copies; the film was produced for $\$ 125$ million by the Academy Award-winning team of director Ron Howard and screenwriter Akiva Goldsman.

8. Sue Birtwistle and Susie Conklin, The Making of Pride and Prejudice (London: Penguin Books and BBC Books, 1995).

9. For more extravagant royal festival scenes from the same period, see Vatel (2000), directed by Roland Joffé, depicting the fête of 1671 in which Louis, Le Grand Condé, entertained Louis XIV at the Château of Chantilly. 10. Fatimah Tobing Rony, "The Last Emperor," Film Quarterly 42, no. 2 (Winter 1988-89), 47-52; and Paul G. Pickowicz, "The Last Emperor," The American Historical Review 94, no. 4 (Oct. 1989), 1035-36.

11. Bergdoll, "Altered States of Vision," xvi-xvii.

12. See http://en.chateauversailles.fr/discover-the-estate/the-palace/thepalace/the-hall-of-mirrors for recent appearance.

13. Westminster's width is 71.9 feet (nave and two aisles) compared with York's 106 feet; its height is 102 feet compared with 92 feet; and the width of its nave is 37.9 feet compared with 53 feet.

14. Sir George Gilbert Scott, The Gleanings from the Westminster Abbey (Oxford and London: J. Henry and J. Parker, 1861). However, the triforium floor was not built until the time of Christopher Wren, and is incomplete. Gilbert Hamerton, ed., The Portfolio: An Artistic Periodical (London: Seeley and Co. Limited, 1889), 123. 
15. London Metropolitan Archives p5429268; illustrated at http://collage. cityoflondon.gov.uk/collage/app?service=external/Item\&sp=Zwestminster+ abbey\&sp=17971\&sp=X (accessed 4 May 2010).

16. Robert Branner, "Westminster Abbey and the French Court Style," FSAH 23, no. 1 (Mar. 1964), 3-18.

17. The position of the choir in the west of the crossing is less frequent but not without other examples, including Peterborough and St. Albans. In some cases the choir occupies the crossing, as is the case at Gloucester and Norwich. 18. Yuriko Saito, "The Japanese Aesthetics of Imperfection and Insufficiency," The fournal of Aesthetics and Art Criticism 55, no. 4 (Autumn 1997), 377-85.

19. Okakura Kakuzo, The Book of Tea (London and New York: G.P. Putnam's Sons, 1906), 145-46.

20. In David Starkey's Elizabeth (2000) the actors (Imogen Slaughter as Elizabeth) have nonspeaking roles for the most part, with Starkey as the commentator. Compare also the film Gladiator and the computer models of the "Rome Reborn" project at the Institute for Advanced Technology in the Humanities at http://www.romereborn.virginia.edu/.

21. Anthony Vidler, "The Explosion of Space: Architecture and the Filmic Imaginary," in Film Architecture: Set Designs from Metropolis to Blade Runner, ed. Dietrich Neumann (Munich and New York: Prestel, 1996), 13-25. See also Erwin Panofsky, "Style and Medium in the Motion Pictures," originally published in 1934, in Film Theory and Criticism: Introductory Readings ed. Gerald Mast and Marshall Cohen (New York: Oxford University Press, 1985), 215-33.

22. Sergei Eisenstein, Film Form: Essays in Film Theory, ed. and trans. Jay Leyda (New York: Harcourt, 1949), 45.

23. Hugo Münsterberg, The Photoplay: A Psychological Study (New York and London: D. Appleton and Company, 1916), 172-73.

24. Hans Dieter Schaal, Learning from Hollywood: Architecture and Film (Stuttgart and London: Edition Axel Menges, 1996), 14. 